\title{
THEORETICAL MODEL FOR DOUBLE-SKINNED CONCRETE-FILLED- STEEL-TUBULAR COLUMNS WITH EXTERNAL CONFINEMENT
}

\author{
Chun Xiao DONG ${ }^{\mathrm{a}}$, Johnny Ching Ming $\mathrm{HO}^{\mathrm{b}}$ \\ ${ }^{a}$ Department of Civil Engineering, The University of Hong Kong, Pok Fu Lam Road, Hong Kong \\ ${ }^{b}$ School of Civil Engineering, The University of Queensland, Brisbane, Australia
}

Received 25 Oct 2012; accepted 02 Jan 2013

\begin{abstract}
Recent advances in the production of super-fine cement and filler technology has made the production of high-strength concrete (HSC) of $120 \mathrm{MPa}$ practicable in the industry. Nonetheless, the application of such HSC in real construction is still limited. One of the reasons that inhibits the use of HSC is the brittleness, which causes HSC structures to fail explosively if the concrete confinement is not adequate. The traditional method of installing transverse steel as confinement is not feasible in HSC structures, as the steel will be too congested to ensure proper concrete placing. To overcome the problem, double-skinned high-strength concrete-filled-steel-tubular (HSCFST) columns has been advocated, which could provide large, continuous and uniform confinement to HSC. However, a major shortcoming of the double-skinned HSCFST columns is the imperfect interface bonding that occurs at the elastic stage that reduces the elastic strength and stiffness of columns. To improve the situation, the authors have verified previously that using external steel rings on the outer steel tube can successfully restrict the dilation of HSCFST columns and thus restore an intact interface bonding condition. As a continued study, the authors will in this paper develop a theoretical model for predicting the uni-axial load-carrying capacity of doubled-skinned HSCFST columns.
\end{abstract}

Keywords: columns, concrete-filled, double-skin tubular, external confinement, rings.

\section{Introduction}

Because of the recent rapid development of superfine materials such as micro-silica and superfine cement, as well as the matured filler technology (Goldman, Bentur 1993; Haque, Kayali 1998), it is now fairly easy to produce ordinary high-strength concrete (HSC) of compressive strength up to $120 \mathrm{MPa}$. The advantage of using HSC over normal-strength concrete (NSC) is that it increases considerably the strength-to-weight ratio, which can decrease the required construction materials and demolition wastes. It also saves extra floor space for maximizing usable areas. Furthermore, due to its larger elastic stiffness, it effectively limits the overall and inter-storey drift ratios of tall buildings to within the tolerance of serviceability limit state. However, despite these appealing merits, the application of HSC in column construction is still not very common. The maximum concrete strength that is commonly adopted in practical construction is limited to 60-80 MPa, which is under-utilising the construction materials and wasting available floor space that can possibly be saved.

One of the major reasons that inhibits the use of HSC is its brittleness (Gettu et al. 1990; Cusson, Paultre 1994; Marzouk, Chen 1995; Zhou et al. 1995; Ho, Zhou
2011), which needs to have substantial confinement to protect the concrete core from explosive failure. The traditional method of utilizing transverse steel in the form of closed hoops or ties for NSC reinforced concrete (RC) columns is not applicable in HSC columns, because the transverse reinforcement required for providing sufficient confinement against explosive failure is too congested to enable good placing quality of concrete. In order to have a breakthrough in the maximum limit of concrete strength that can be practically used in column construction, special type of confinement that can provide larger, more continuous and uniform confining pressure to concrete should be devised. One of the most ineffective reasons for adopting transverse reinforcement in RC columns is the concrete arching action, which decreases the effectively confined concrete area. In order to eliminate this action, a continuous concrete confinement in the form of steel tube has been advocated. Two composite structural forms of high-strength concrete-filled-steel-tubular (HSCFST) column that contains one (i.e. single-skinned) or two hollow steel tubes (i.e. double-skinned) for concrete confinement were put forward.

From structural point of view, these forms of composite column construction can provide larger axial

Corresponding author: Johnny Ching Ming Ho

E-mail: johnny.ho@uq.edu.au 
strength (Wright et al. 1991; Wei et al. 1995; Zhao, Grzebieta 2002; Zhao et al. 2002; Giakoumelis, Lam 2004; Tao et al. 2004; Young, Ellobody 2006; Dabaon et al. 2009; Kuranovas et al. 2009; de Oliveira et al. 2010; Szmigiera et al. 2010), bending stiffness, moment capacity (Elchalakani et al. 2001; Lin, Tsai 2001; Zhao, Grzebieta 2002; Chitawadagi, Narasimhan 2009; Lu et al. 2009), better ductility (Kitada 1998; Schneider 1998; Elremaily, Azizinamini 2002; Zhao, Grzebieta 2002; Lin, Tsai 2001) and excellent seismic performance (Varma et al. 2002; Sakino et al. 2004; Yang, Han 2008; Lu et al. 2010; Zhao et al. 2010; Montejo et al. 2012). From cost effectiveness point of view, the tubes act as both the longitudinal reinforcement that reduces the cost for steel bars fixing and formwork that reduces the cost for formwork fabrication. From environmental point of view, the size of HSCFST column can be up to $50 \%$ smaller than that of HSC columns providing the same load-carrying capacity. It successfully decreases the embodied energy level in the building structures. Compared with single-skinned HSCFST columns, double-skinned HSCFST columns further improve the strength-to-weight ratio by replacing the bulky central concrete with an inner steel tube with smaller cross-sectional area. It also provides a dry atmosphere within the inner steel tube, which is particularly useful to house sub-sea oil production facilities for offshore structures (Shakir-Khalil 1991; Yang et al. 2008; Zhao et al. 2010). For other structures, the dry environment is also useful for accommodation of conduits, drainage and maintenance check purposes.

However, one major problem (Wei et al. 1995; Huang et al. 2011) for the HSCFST columns is the imperfect steel-concrete interface bonding that occurs in the elastic stage since steel dilates more than concrete (Köster, Franz 1961; Persson 1999; Ferretti 2004; Lu, Hsu 2007). Consequently, the confinement is not activated in the initial elastic stage, which decreases the elastic strength and stiffness. In order to resolve this problem, the authors have previously proposed to use external confinement in the form of steel rings to restrict the dilation of HSCFST columns for restoring an intact interface bonding (Dong, Ho 2012; Ho, Luo 2012; Lai, Ho 2014). A preliminary test programme has been carried out and the results showed that the Poisson's ratios of columns can be successfully reduced to close to 0.2 , which is that of plain concrete. It verified that the concrete would be in perfect bond with the steel skin under the extra confinement effect provided by the steel rings. In the past, some efforts had been spent on installing internal stiffeners and binding bars for achieving similar purpose (Huang et al. 2002; Tao et al. 2005; Cai, He 2006; Tao et al. 2007). However, it is worth noting that the welding of these internal stiffeners and binding bars is more difficult than that of the proposed external confinement, in particular for doubled-skinned HSCFST columns where the gap between steel skins is very limited.

In order to investigate the behaviour of unconfined and ring-confined double-skinned HSCFST column, it is necessary to develop a numerical model for evaluating the uni-axial load carrying capacity of double-skinned CFST column. Previously, some research work has been done on the theoretical model for double-skinned HSCFST columns (Han et al. 2004; Tao et al. 2004; Huang et al. 2010; Tan, Zhang 2010; Uenaka et al. 2010; Zhao et al. 2010; Hu, Su 2011). However, there was no such model proposed for double-skinned HSCFST columns containing external confinement. Furthermore, there is no design model and guidelines provided in Eurocode 4 (EC4 2004) for strength prediction of externally confined doubleskinned HSCFST columns. Therefore, the design according to the Eucocode 4 will be very conservative. To fill up the gap, the authors will in this paper derive a theoretical model for evaluating the uni-axial load-carrying capacity of double-skinned HSCFST columns based on the results obtained for twenty double-skinned HSCFST columns in a previous experimental programme. For verification, the proposed model will be used to calculate the theoretical strength of double-skinned HSCFST columns tested by the authors as well as other researchers.

\section{Details of specimens}

In a previous study conducted by the authors (Dong, Ho 2012), a total of twenty concrete-filled double-skin tubular columns have been fabricated and tested under uniaxial compression load. The specimens were divided into four groups based on the provision of confinement, concrete cylinder strength and the hollow ratio $\chi$ (defined as $\left.\chi=\frac{D_{i}}{D_{o}-2 t_{o}}\right)$, where $D_{i}$ and $D_{o}$ are the diameters of the inner and outer tubes respectively, $t_{o}$ is the thickness of the outer tube: (1) Four double-skinned CFST columns of hollow ratio 0.56 and external steel rings of various spacing $\left(5 t_{o}, 10 t_{o}, 15 t_{o}\right.$ and $\left.20 t_{o}\right)$; (2) four double-skinned CFST columns of hollow ratio 0.72 and external steel rings of various spacing $\left(5 t_{o}, 10 t_{o}, 15 t_{o}\right.$ and $20 t_{o}$ ); (3) one double-skinned CFST column of hollow ratio 0.56 but without external steel rings; (4) one doubleskinned CFST column of hollow ratio of 0.72 but without external steel rings. In each of the two sets of specimens (i.e. $\chi=0.56$ and 0.72 ), concrete cylinder strength of 50 and $85 \mathrm{MPa}$ were adopted. The grade of both inner and outer steel tubes was S355 produced as per BS EN 10210-2: 2006 (2006). For all tested specimens, the thickness of both inner and outer steel tubes was $5 \mathrm{~mm}$ and the diameter of outer steel tube was $168.3 \mathrm{~mm}$ (measured to the outer face). For columns of hollow ratios 0.56 and 0.72 , the diameters of inner tubes were 88.9 and $114.3 \mathrm{~mm}$ respectively (measured to the outer face). The total height of the specimens was $330 \mathrm{~mm}$ (aspect ratio of 2). The section and material properties of the specimens are summarised in Table 1.

The external steel rings were made of mild steel round bars of $8 \mathrm{~mm}$ diameter and the yield strength was $f_{y, R}=300 \mathrm{MPa}$. The rings were welded to the outer tubes at different spacing and the lap length was ten times the 
Table 1. Details of specimens and materials' properties

\begin{tabular}{lcccccccc}
\hline Specimen label & $\begin{array}{c}D_{i} \\
(\mathrm{~mm})\end{array}$ & $\begin{array}{c}t_{i} \\
(\mathrm{~mm})\end{array}$ & $\begin{array}{c}f_{y, i} \\
(\mathrm{MPa})\end{array}$ & $\begin{array}{c}D_{o} \\
(\mathrm{~mm})\end{array}$ & $\begin{array}{c}t_{o} \\
(\mathrm{~mm})\end{array}$ & $\begin{array}{c}f_{y, o} \\
(\mathrm{MPa})\end{array}$ & $\begin{array}{c}f_{c}^{\prime}{ }_{c} \\
(\mathrm{MPa})\end{array}$ & $\begin{array}{c}f_{y, R} \\
(\mathrm{MPa})\end{array}$ \\
\hline D-0.56-50-5 & 88.9 & 5 & 450 & 168.3 & 5 & 360 & 50 & 300 \\
D-0.56-50-10 & 88.9 & 5 & 450 & 168.3 & 5 & 360 & 50 & 300 \\
D-0.56-50-15 & 88.9 & 5 & 450 & 168.3 & 5 & 360 & 50 & 300 \\
D-0.56-50-20 & 88.9 & 5 & 450 & 168.3 & 5 & 360 & 50 & 300 \\
D-0.56-50-0 & 88.9 & 5 & 450 & 168.3 & 5 & 360 & 50 & N/A \\
D-0.56-85-5 & 88.9 & 5 & 450 & 168.3 & 5 & 360 & 85 & 300 \\
D-0.56-85-10 & 88.9 & 5 & 450 & 168.3 & 5 & 360 & 85 & 300 \\
D-0.56-85-15 & 88.9 & 5 & 450 & 168.3 & 5 & 360 & 85 & 300 \\
D-0.56-85-20 & 88.9 & 5 & 450 & 168.3 & 5 & 360 & 85 & 300 \\
D-0.56-85-0 & 88.9 & 5 & 450 & 168.3 & 5 & 360 & 85 & N/A \\
D-0.72-50-5 & 114.3 & 5 & 430 & 168.3 & 5 & 360 & 50 & 300 \\
D-0.72-50-10 & 114.3 & 5 & 430 & 168.3 & 5 & 360 & 50 & 300 \\
D-0.72-50-15 & 114.3 & 5 & 430 & 168.3 & 5 & 360 & 50 & 300 \\
D-0.72-50-20 & 114.3 & 5 & 430 & 168.3 & 5 & 360 & 50 & 300 \\
D-0.72-50-0 & 114.3 & 5 & 430 & 168.3 & 5 & 360 & 50 & N/A \\
D-0.72-85-5 & 114.3 & 5 & 430 & 168.3 & 5 & 360 & 85 & 300 \\
D-0.72-85-10 & 114.3 & 5 & 430 & 168.3 & 5 & 360 & 85 & 300 \\
D-0.72-85-15 & 114.3 & 5 & 430 & 168.3 & 5 & 360 & 85 & 300 \\
D-0.72-85-20 & 114.3 & 5 & 430 & 168.3 & 5 & 360 & 85 & 300 \\
D-0.72-85-0 & 114.3 & 5 & 430 & 168.3 & 5 & 360 & 85 & N/A \\
\hline & & & & & & & &
\end{tabular}

diameter of the steel bar $(80 \mathrm{~mm})$. Each ring was welded to the outer tube at eight locations with a central angle of $45^{\circ}$ separated from each other. Figures 1 and 2 show the test setup and the details of the specimens.

A naming system consisting of one letter and three numbers has been used to represent the specimens. For instance, 'D-0.72-50-5' represents a double-skinned CFST column (indicated by the first letter "D"), a hollow ratio of 0.72 (indicated by the first number " 0.72 "), a concrete cylinder strength of about $50 \mathrm{MPa}$ on the testing day (indicated by the second number " 50 ") and lastly five times the thickness of the outer steel tube as the ring spacing (indicated by the last number " 5 "). Alternatively, 'D-0.56-85-0' represents a double-skinned CFST column (indicated by the first letter "D") with a hollow ratio of

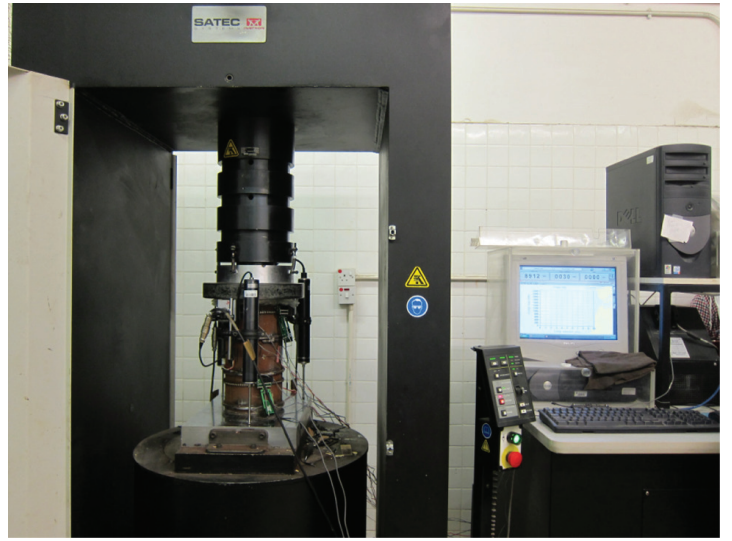

Fig. 1. Test setup

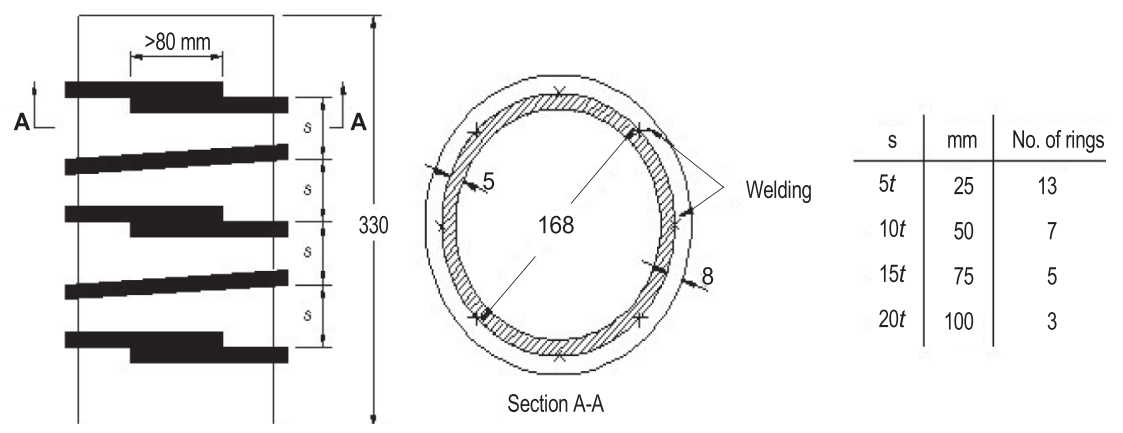

Fig. 2. Details of external steel rings of specimens 
0.56 (indicated by the first number " 0.56 "), a concrete cylinder strength of about $85 \mathrm{MPa}$ on the testing day (indicated by the second number " 85 "), and lastly no external steel ring (i.e. zero spacing indicated by the last number " 0 ").

\section{Theoretical model for confined double-skinned CFST columns}

A lot of research has been conducted on the theoretical models of double-skinned HSCFST columns (Tao, Han 2006; Tan, Zhang 2010; Uenaka et al. 2010; Hu, Su 2011). Nevertheless, the theoretical models were mainly for columns without external confinement. Therefore, the application of such models will underestimate the strength capacity of double-skinned HSCFST columns installed with external confinement. Furthermore, the existing Eurocode 4 (EC4 2004) is not suitable for designing confined double-skinned HSCFST columns because no guidelines are provided to account for the enhanced strength of concrete and steel tube due to the provision of external confinement. Therefore in this paper, the authors will propose a theoretical model for predicting the uni-axial strength of confined double-skinned HSCFST columns. The validity of the theoretical model will be verified by comparing the theoretical results with the experimental results obtained previously by the authors.

The formulas for evaluating the axial capacity of the double-skinned CFST columns with/without external confinement are shown as follows:

$$
\begin{aligned}
& N_{p}=N_{i}+N_{o}+N_{c c} ; \\
& N_{i}=f_{i} A_{i} ; \\
& N_{o}=f_{o} A_{o} ; \\
& N_{c c}=f_{c c} A_{c c},
\end{aligned}
$$

where $N_{p}, N_{i}, N_{o}$ and $N_{c c}$ in Eqn (1) represent the predicted axial load capacity of double-skinned CFST column with/without external confinement, axial load sustained by the inner steel tube, outer steel tube and core concrete respectively. In Eqn (2), $f_{i}$ and $f_{o}$ are the axial stresses in the inner and outer tubes respectively under bi-axial stress state; $f_{c c}$ is the axial stress in the core concrete under the confining pressure $f_{r} . A_{i}, A_{o}$ and $A_{c c}$ are the crosssection areas of the inner tube, outer tube and the core concrete respectively. In this model, it is assumed that the confining pressure is uniform along the total height of the specimens. The confining pressure provided by the inner and outer steel tubes is the same based on force equilibrium. The radial stresses in the steel tubes are negligible due to the large contact area. Figure 3(a) shows the free body diagram of the outer steel tube together with the external steel rings, if any, subjected to confining pressure $f_{r}$. The hoop tensile stress developed in the outer tube can

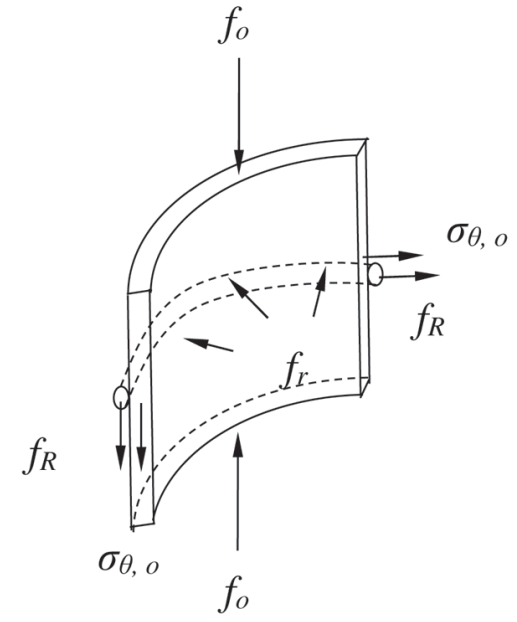

Fig. 3(a). Free body diagram of the outer tube

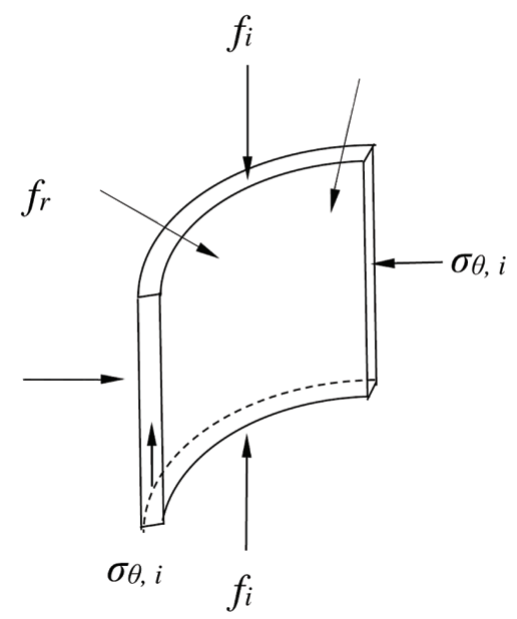

Fig. 3(b). Free body diagram of the inner tube

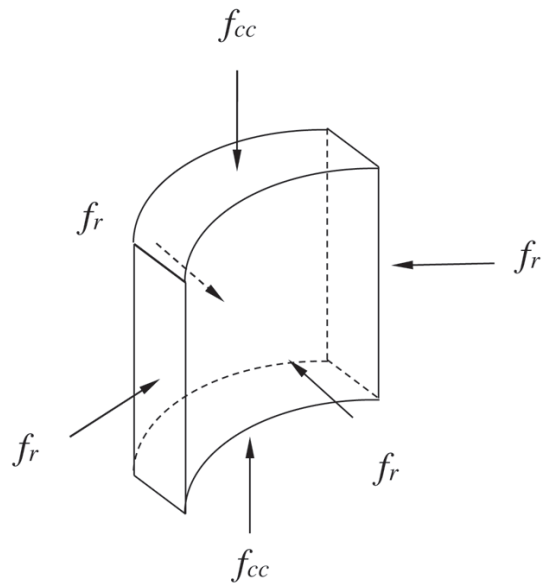

Fig. 3(c). Free body diagram of the core concrete 
be derived by considering the force equilibrium of the outer tube under the confining pressure provided by the concrete and external steel rings. The hoop tensile stress $\sigma_{\theta, o}$ for ring-confined specimens is shown in Eqn (3a):

$$
\sigma_{\theta, o}=\frac{-f_{r}\left(D_{o}-2 t_{o}\right) h+2 n A_{R} \sigma_{R}}{2 t_{o} h},
$$

where: $\sigma_{\theta, o}$ is the hoop tensile stress developed in the outer tube; $\sigma_{R}$ is the tensile stress acting in the external rings; $A_{R}$ is the cross-section area of each steel ring; $D_{o}$ and $t_{o}$ represent the diameter and thickness of the outer steel tube; $h$ stands for the total height of the column; $n$ is the number of the external steel rings welded on the specimen. For unconfined double-skinned CFST column, take $n=A_{R}=0$, and Eqn (3a) is simplified to:

$$
\sigma_{\theta, o}=-\frac{f_{r}\left(D_{o}-2 t_{o}\right)}{2 t_{o}} .
$$

Figure 3(b) shows the free body diagram of the inner steel tube subjected to confining pressure $f_{r}$. The hoop compressive stress developed in the inner tube is denoted by $\sigma_{\theta, i}$. By considering the force equilibrium of the inner tube, Eqn (4) can be established as follows:

$$
\sigma_{\theta, i}=\frac{f_{r} D_{i}}{2 t_{i}}
$$

where: $\sigma_{\theta, i}$ is the hoop compressive stress developed in the inner tube; $D_{i}$ and $t_{i}$ represent the diameter and thickness of the inner steel tube. Under bi-axial stress state, the yield strength of the outer and inner tubes is not be the same as the uni-axial yield strength. Their respective yield strength at bi-axial stress state can be determined by the von Mises yield criterion. Eqns (5a) and (5b) show the von Mises yield criterion for inner and outer steel tube, respectively:

$$
\begin{gathered}
f_{o}^{2}-f_{o} \sigma_{\theta, o}+{\sigma_{\theta, o}}^{2}=f_{y, o}{ }^{2} ; \\
f_{i}^{2}-f_{i} \sigma_{\theta, i}+{\sigma_{\theta, i}}^{2}=f_{y, i}{ }^{2},
\end{gathered}
$$

where $f_{y, o}, f_{y, i}$ are the uni-axial yield strength of the steel tubes. To find out the values of the yield stresses of the outer and inner tubes, it is necessary to determine the hoop stress $\sigma_{\theta, o}$ of the outer tube at yielding. Previously, Hatzigeorgiou (2008) reported that a major parameter that affects the hoop stress is the diameter-to-thickness ratio. The hoop stress is correlated to the uni-axial yield strength by a new parameter $\alpha_{\theta}$, which depends on the diameter-to-thickness ratio and yield strength of steel tube. The formulas proposed by Hatzigeorgiou (2008) relating the hoop stress $\sigma_{\theta, o}$ of the outer tube and the diameter-to-thickness ratio $\left(D_{o} / t_{o}\right)$ and yield strength $\left(f_{y, o}\right)$ are expressed in Eqn (6):

$$
\begin{gathered}
\sigma_{\theta, o}=\alpha_{\theta} f_{y, o} ; \\
\alpha_{\theta}=\exp \left(\ln \left(\frac{D_{0}}{t_{0}}\right)+\ln \left(f_{y, o}\right)-11\right) \leq 1 .
\end{gathered}
$$

By calculating the hoop stress at yielding, the yield strength of steel tubes under bi-axial state, as well as the confining pressure $f_{r}$, can be determined. The strength calculated can then be substituted back into Eqns (2a) and (2b) to obtain the compressive stresses in the outer and inner tubes. Normally, in order to fully utilise the yield strength of the steel tubes to confine the in-filled concrete, the steel tube will be designed to be sufficiently strong that no stability failure would occur before the steel tubes yield and concrete crushes. This can be verified by checking the buckling strain $\varepsilon_{l b}$ of the steel tube as shown in Eqn (7) (O’Shea, Bridge 1997):

$$
\begin{gathered}
\varepsilon_{l b}=\varepsilon_{y}\left(0.2139 R^{-1.413}\right) ; \\
R=\frac{D_{o}}{t_{o}} \frac{f_{y, o}}{E_{s o}},
\end{gathered}
$$

where: $\varepsilon_{y}$ is the yield strain of the steel tube under uniaxial compression; and $E_{s o}$ is the elastic modulus of steel tube. In order to verify that the steel tube can reach the yield strength before any instability occurs, it needs to check that $\varepsilon_{l b} \geq \varepsilon_{y}$ (or $R \leq 0.336$ ). Otherwise, the stress in the steel tube should be taken as $\varepsilon_{l b} E_{s o}$.

For the compression force in the confined concrete, the confined concrete strength can be assessed by the Eqn (8) proposed by Mander and Priestley (1988). Figure 3(c) shows the free body diagram of core concrete.

$$
f_{c c}=f_{c}{ }^{\prime}+4.1 f_{r},
$$

where $f_{c}{ }^{\prime}$ is unconfined concrete cylinder strength.

The following summarises the procedure to determine the uni-axial strength of a double-skinned CFST column with/without confinement:

1. Determine the hoop stress of the outer steel tube $\sigma_{\theta, o}$ by Eqn (6);

2. Determine the confining pressure $f_{r}$ by substituting $\sigma_{\theta, o}$ into Eqn (3a) and take $s_{R}$ equal to the yield strength of ring $f_{y, R}$ assuming that steel rings yield when the column attains uni-axial strength;

3. Calculate the yield strength of the outer tube $f_{o}$ and inner tube $f_{i}$ under bi-axial state by Eqns (5a) and (5b) respectively;

4. Calculate the confined concrete strength $f_{c c}$ by substituting $f_{r}$ into Eqn (8);

5. Calculate the uni-axial load-carrying capacity of double-skinned CFST columns by substituting $f_{i}, f_{o}$ and $f_{c c}$ into Eqns (2a), (2b) and (2c) respectively;

6. Check the stability of the column by verifying that the buckling strain $\varepsilon_{l b}$ is larger than the yield strength of steel tube $\varepsilon_{y}$. Otherwise, the stresses in 
the outer and inner tube should be taken as the buckling strain multiplied by the elastic modulus.

\section{Verification with test results}

\subsection{Verification of ring-confined double-skinned CFST columns}

The theoretical axial load-carrying capacities of the tested ring-confined double-skinned CFST columns specimens evaluated by the proposed analytical model are listed in Table 2(a). The theoretical results were also compared with the predicted uni-axial strength as per Eurocode 4 Part 1-1 (EC4 2004) in the same table. It is worth noting that the formula in Eurocode 4 does not take into account the effect of external confinement.

In the table, $N_{p}$ represents the predicted load-carrying capacity evaluated by authors' model, $N_{t}$ represents the experimentally measured load-carrying capacity and $N_{E C}$ represents the load-carrying capacity evaluated using Eurocode 4. From the table, it is observed that:

1. The average $N_{p} / N_{t}$ ratios for ring-confined doubleskinned CFST columns with hollow ratio of 0.56 and concrete strength of 50 and $85 \mathrm{MPa}$ are 0.923 and 0.964 respectively. The maximum difference between the theoretical and test results is $8.3 \%$ underestimation.
2. The average $N_{p} / N_{t}$ ratios for ring-confined doubleskinned CFST columns with hollow ratio of 0.72 and concrete strength of 50 and $85 \mathrm{MPa}$ are 0.903 and 0.965 respectively. The maximum difference between the theoretical and test results is $2.3 \%$ overestimation and $15.9 \%$ underestimation.

3. The average $N_{p} / N_{t}$ ratio for all ring-confined double-skinned CFST columns is 0.940. Comparing with the average $N_{E C} / N_{t}$ ratio for all ring-confined double-skinned CFST columns, which is 0.815 , it is evident that the proposed model can predict much more accurately the load-carrying capacity of ringconfined double-skinned CFST columns by taking into account the confinement effect provided by the external rings.

\subsection{Verification of unconfined double-skinned CFST columns}

The analytical model has also been applied to evaluate the theoretical axial load-carrying capacity of unconfined double-skinned CFST columns tested by the authors and by other previous researchers (Wei et al. 1995; Tao et al. 2004; Lin, Tsai 2001; Uenaka et al. 2010; Han et al. 2011). Apart from comparing with the experimental results, the theoretical results were also compared with the

Table 2(a). Comparison between theoretical and experimental results of ring-confined double-skinned CFST columns

\begin{tabular}{|c|c|c|c|c|c|}
\hline Specimen Label & $\begin{array}{c}N_{p} \\
(\mathrm{kN})\end{array}$ & $\begin{array}{l}N_{E C} \\
(\mathrm{kN})\end{array}$ & $\begin{array}{c}N_{t} \\
(\mathrm{kN})\end{array}$ & $\frac{N_{E C}}{N_{t}}$ & $\frac{N_{p}}{N_{t}}$ \\
\hline D-0.56-50-5 & 3212 & 2474 & 3464 & 0.714 & 0.927 \\
\hline D- $0.56-50-10$ & 2878 & 2474 & 3107 & 0.796 & 0.926 \\
\hline D- $0.56-50-15$ & 2723 & 2474 & 2971 & 0.833 & 0.917 \\
\hline D- $0.56-50-20$ & 2639 & 2474 & $-\#$ & - \# & - \# \\
\hline Average & & & & 0.781 & 0.923 \\
\hline D-0.56-85-5 & 3684 & 2934 & 3788 & 0.775 & 0.973 \\
\hline D- $0.56-85-10$ & 3350 & 2934 & 3394 & 0.864 & 0.987 \\
\hline D- $0.56-85-15$ & 3194 & 2934 & 3434 & 0.854 & 0.930 \\
\hline D- $0.56-85-20$ & 3109 & 2934 & 3222 & 0.911 & 0.965 \\
\hline Average & & & & 0.851 & 0.964 \\
\hline D-0.72-50-5 & 3005 & 2280 & 3209 & 0.711 & 0.936 \\
\hline D- $0.72-50-10$ & 2620 & 2280 & 2873 & 0.794 & 0.912 \\
\hline D- $0.72-50-15$ & 2493 & 2280 & 2964 & 0.769 & 0.841 \\
\hline D- $0.72-50-20$ & 2480 & 2280 & 2688 & 0.848 & 0.923 \\
\hline Average & & & & 0.781 & 0.903 \\
\hline D-0.72-85-5 & 3339 & 2605 & 3265 & 0.798 & 1.023 \\
\hline D- $0.72-85-10$ & 2950 & 2605 & 3049 & 0.854 & 0.968 \\
\hline D- $0.72-85-15$ & 2823 & 2605 & 3037 & 0.858 & 0.930 \\
\hline D- $0.72-85-20$ & 2809 & 2605 & 2995 & 0.870 & 0.938 \\
\hline Average & & & & 0.845 & 0.965 \\
\hline (Overall) Average & & & & 0.815 & 0.940 \\
\hline (Overall) Standard deviation & & & & 0.058 & 0.041 \\
\hline $\begin{array}{l}\text { (Overall) Maximum } \\
\text { (Overestimation) }\end{array}$ & & & & N/A & 1.023 \\
\hline $\begin{array}{l}\text { (Overall) Minimum } \\
\text { (Underestimation) }\end{array}$ & & & & 0.711 & 0.841 \\
\hline
\end{tabular}

\# Result is NOT included because of poor concrete compaction. 
Table 2(b). Comparison between theoretical and experimental results of unconfined double-skinned CFST columns

\begin{tabular}{|c|c|c|c|c|c|c|c|c|c|c|c|c|c|c|}
\hline $\begin{array}{l}\text { Specimen } \\
\text { label }\end{array}$ & $\begin{array}{l}N_{p 1} \\
(\mathrm{kN})\end{array}$ & $\begin{array}{l}N_{p 2} \\
(\mathrm{kN})\end{array}$ & $\begin{array}{l}N_{p 3} \\
(\mathrm{kN})\end{array}$ & $\begin{array}{c}N_{p 4} \\
(\mathrm{kN})\end{array}$ & $\begin{array}{l}N_{E C} \\
(\mathrm{kN})\end{array}$ & $\begin{array}{c}N_{p} \\
(\mathrm{kN})\end{array}$ & $\begin{array}{c}N_{t} \\
(\mathrm{kN})\end{array}$ & $\frac{N_{p 1}}{N_{t}}$ & $\frac{N_{p 2}}{N_{t}}$ & $\frac{N_{p 3}}{N_{t}}$ & $\frac{N_{p 4}}{N_{t}}$ & $\frac{N_{E C}}{N_{t}}$ & $\frac{N_{p}}{N_{t}}$ & 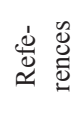 \\
\hline D-0.56-50-0 & 2099 & 2486 & 2848 & 2417 & 2474 & 2561 & 2852 & 0.736 & 0.872 & 0.999 & 0.847 & 0.867 & 0.898 & \multirow{4}{*}{ 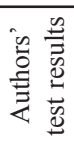 } \\
\hline D- $0.56-85-0$ & 2517 & 2965 & 3320 & 2856 & 2934 & 3032 & 3218 & 0.782 & 0.873 & 1.032 & 0.888 & 0.912 & 0.942 & \\
\hline D- $0.72-50-0$ & 1484 & 2335 & 2354 & 2205 & 2280 & 2379 & 2674 & 0.555 & 0.921 & 0.88 & 0.825 & 0.853 & 0.890 & \\
\hline D- $0.72-85-0$ & 1727 & 2669 & 2684 & 2513 & 2605 & 2709 & 2994 & 0.577 & 0.892 & 0.896 & 0.839 & 0.870 & 0.905 & \\
\hline A1-1 & 198 & 272 & 239 & 261 & 269 & 277 & 283 & 0.700 & $-* *$ & $-* *$ & 0.922 & 0.951 & 0.979 & \multirow{26}{*}{ 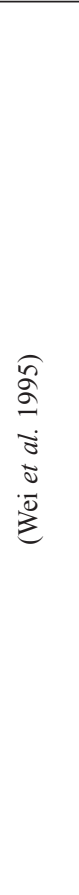 } \\
\hline A1-2 & 200 & 259 & 229 & 250 & 258 & 265 & 285 & 0.702 & $-* *$ & -** & 0.877 & 0.905 & 0.930 & \\
\hline A2-1 & 153 & 322 & 278 & 308 & 316 & 330 & 348 & 0.440 & $-* *$ & $-* *$ & 0.885 & 0.908 & 0.948 & \\
\hline A2-2 & 175 & 308 & 269 & 295 & 303 & 312 & 348 & 0.503 & $-* *$ & -** & 0.848 & 0.871 & 0.897 & \\
\hline A3-1 & 133 & 365 & 310 & 346 & 353 & 365 & 395 & 0.337 & $-* *$ & -** & 0.876 & 0.894 & 0.924 & \\
\hline A3-2 & 139 & 367 & 310 & 347 & 355 & 367 & 395 & 0.352 & $-* *$ & -** & 0.878 & 0.899 & 0.929 & \\
\hline B1-1 & 313 & 317 & 306 & 306 & 323 & 332 & 330 & 0.948 & 0.960 & $-* *$ & 0.927 & 0.979 & 1.006 & \\
\hline B1-2 & 309 & 308 & 298 & 298 & 314 & 323 & 335 & 0.922 & 0.918 & _** & 0.890 & 0.937 & 0.964 & \\
\hline B2-1 & 322 & 358 & 339 & 344 & 363 & 374 & 386 & 0.834 & 0.927 & $\_* *$ & 0.891 & 0.940 & 0.969 & \\
\hline B2-2 & 328 & 363 & 346 & 348 & 366 & 377 & 395 & 0.830 & 0.918 & $\_* *$ & 0.881 & 0.927 & 0.954 & \\
\hline C1-1 & 361 & 345 & 354 & 334 & 359 & 368 & 378 & 0.955 & 0.911 & $-* *$ & 0.884 & 0.950 & 0.974 & \\
\hline C1-2 & 359 & 340 & 350 & 330 & 354 & 363 & 385 & 0.932 & 0.882 & _** & 0.857 & 0.919 & 0.943 & \\
\hline $\mathrm{C} 2-1$ & 386 & 383 & 393 & 369 & 395 & 406 & 432 & 0.894 & 0.887 & 0.910 & 0.854 & 0.914 & 0.940 & \\
\hline $\mathrm{C} 2-2$ & 385 & 376 & 387 & 362 & 388 & 398 & 408 & 0.944 & 0.921 & 0.949 & 0.887 & 0.951 & 0.975 & \\
\hline D1-1 & 307 & 280 & 273 & 278 & 292 & 275 & 283 & 1.085 & - ** & -** & 0.982 & 1.032 & 0.972 & \\
\hline D2-1 & 258 & 255 & 227 & 252 & 256 & 261 & 299 & 0.863 & $-* *$ & $-* *$ & 0.843 & 0.856 & 0.873 & \\
\hline D3-1 & 332 & 309 & 298 & 306 & 321 & 325 & 357 & 0.930 & _** & $-* *$ & 0.857 & 0.899 & 0.910 & \\
\hline D4-1 & 378 & 344 & 352 & 341 & 364 & 369 & 380 & 0.995 & 0.905 & _** & 0.897 & 0.958 & 0.971 & \\
\hline D5-1 & 420 & 384 & 425 & 381 & 416 & 426 & 443 & 0.948 & 0.866 & 0.959 & 0.860 & 0.939 & 0.962 & \\
\hline D6-1 & 535 & 525 & 586 & 503 & 631 & 648 & 644 & 0.831 & 0.816 & 0.910 & 0.781 & 0.980 & 1.006 & \\
\hline E1-1 & 320 & 323 & 324 & 310 & 350 & 352 & 357 & 0.896 & 0.904 & _** & 0.868 & 0.980 & 0.986 & \\
\hline E2-1 & 439 & 428 & 463 & 414 & 455 & 451 & 477 & 0.920 & 0.897 & 0.971 & 0.868 & 0.954 & 0.945 & \\
\hline E3-1 & 372 & 373 & 364 & 362 & 385 & 386 & 417 & 0.892 & 0.894 & -** & 0.868 & 0.923 & 0.926 & \\
\hline E4-1 & 588 & 571 & 645 & 555 & 619 & 613 & 598 & 0.983 & 0.955 & 1.079 & 0.928 & 1.035 & 1.025 & \\
\hline E5-1 & 523 & 508 & 537 & 496 & 541 & 538 & 551 & 0.949 & 0.922 & 0.975 & 0.900 & 0.982 & 0.976 & \\
\hline E6-1 & 471 & 473 & 455 & 463 & 487 & 490 & 524 & 0.899 & _** & _** & 0.884 & 0.929 & 0.935 & \\
\hline cc2a & 1552 & 1518 & 2208 & 1881 & 1631 & 1641 & 1790 & 0.867 & 0.848 & 1.234 & 1.051 & 0.911 & 0.917 & \multirow{14}{*}{ 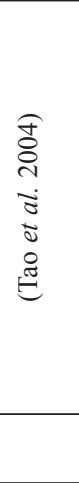 } \\
\hline$c c 2 b$ & 1552 & 1518 & 2208 & 1881 & 1631 & 1641 & 1791 & 0.867 & 0.848 & 1.233 & 1.050 & 0.911 & 0.916 & \\
\hline $\operatorname{cc} 3 \mathrm{a}$ & 1521 & 1474 & 1869 & 1668 & 1548 & 1568 & 1648 & 0.923 & 0.894 & 1.134 & 1.012 & 0.939 & 0.951 & \\
\hline $\operatorname{cc} 3 a$ & 1521 & 1474 & 1869 & 1668 & 1548 & 1568 & 1650 & 0.922 & 0.893 & 1.133 & 1.011 & 0.938 & 0.950 & \\
\hline $\operatorname{cc} 4 a$ & 1151 & 1242 & 1228 & 1252 & 1229 & 1220 & 1435 & 0.802 & _** & $-* *$ & 0.872 & 0.856 & 0.850 & \\
\hline $\operatorname{cc} 4 b$ & 1151 & 1242 & 1228 & 1252 & 1229 & 1220 & 1358 & 0.848 & _** & _** & 0.922 & 0.905 & 0.898 & \\
\hline $\operatorname{cc5a}$ & 753 & 795 & 978 & 812 & 808 & 809 & 904 & 0.833 & 0.880 & 1.082 & 0.898 & 0.894 & 0.895 & \\
\hline $\operatorname{cc} 5 b$ & 753 & 795 & 978 & 812 & 808 & 809 & 898 & 0.839 & 0.885 & 1.089 & 0.904 & 0.900 & 0.901 & \\
\hline cc6a & 2320 & 2208 & 2867 & 2629 & 2339 & 2419 & 2421 & 0.958 & 0.912 & 1.184 & 1.086 & 0.966 & 0.999 & \\
\hline cc6b & 2320 & 2208 & 2867 & 2629 & 2339 & 2419 & 2460 & 0.943 & 0.897 & 1.165 & 1.069 & 0.951 & 0.983 & \\
\hline $\mathrm{cc} 7 \mathrm{a}$ & 3253 & 3048 & 3802 & 3403 & 3189 & 3377 & 3331 & 0.977 & 0.915 & 1.141 & 1.022 & 0.957 & 1.014 & \\
\hline $\mathrm{cc} 7 \mathrm{~b}$ & 3253 & 3048 & 3802 & 3403 & 3189 & 3377 & 3266 & 0.996 & 0.933 & 1.164 & 1.042 & 0.976 & 1.034 & \\
\hline DS-2 & 2417 & 2331 & 2627 & 2222 & 2981 & 2530 & 2750 & 0.879 & 0.848 & 0.955 & 0.808 & 1.084 & 0.920 & \\
\hline DS-6 & 2011 & 1867 & 2087 & 1823 & 2302 & 2098 & 2311 & 0.870 & 0.808 & 0.903 & 0.789 & 0.996 & 0.908 & \\
\hline $\mathrm{c} 10-375$ & 460 & 435 & 580 & 2139 & 518 & 578 & 635 & 0.724 & 0.686 & 0.913 & 3.369 & 0.816 & 0.910 & \multirow{9}{*}{ 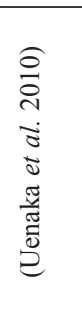 } \\
\hline c10-750 & 433 & 405 & 485 & 1229 & 470 & 518 & 543 & 0.797 & 0.745 & 0.893 & 2.263 & 0.866 & 0.954 & \\
\hline c10-1125 & 360 & 330 & 342 & 328 & 363 & 387 & 378 & 0.952 & 0.872 & $-* *$ & 0.868 & 0.960 & 1.024 & \\
\hline c16-375 & 647 & 603 & 889 & 1088 & 744 & 847 & 852 & 0.759 & 0.708 & 1.043 & 1.277 & 0.873 & 0.994 & \\
\hline $\mathrm{c} 16-750$ & 651 & 595 & 738 & 751 & 700 & 785 & 728 & 0.894 & 0.817 & 1.014 & 1.032 & 0.962 & 1.078 & \\
\hline c16-1125 & 606 & 548 & 550 & 534 & 594 & 646 & 589 & 1.029 & 0.930 & $-* *$ & 0.907 & 1.008 & 1.097 & \\
\hline c23-375 & 738 & 701 & 1057 & 950 & 867 & 905 & 968 & 0.762 & 0.724 & 1.092 & 0.981 & 0.896 & 0.935 & \\
\hline c23-750 & 758 & 708 & 883 & 791 & 829 & 869 & 879 & 0.862 & 0.805 & 1.005 & 0.900 & 0.943 & 0.989 & \\
\hline c23-1125 & 712 & 666 & 652 & 644 & 710 & 758 & 704 & 1.011 & 0.946 & $-* *$ & 0.915 & 1.009 & 1.077 & \\
\hline C1-1 & 2268 & 2350 & 2498 & 2391 & 2489 & 2622 & 2537 & 0.894 & 0.926 & $-* *$ & 0.942 & 0.981 & 1.034 & \multirow{4}{*}{ 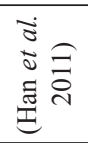 } \\
\hline $\mathrm{C} 1-2$ & 2268 & 2350 & 2498 & 2391 & 2489 & 2622 & 2566 & 0.884 & 0.916 & -** & 0.932 & 0.970 & 1.022 & \\
\hline $\mathrm{C} 2-1$ & 2810 & 2727 & 3476 & 3067 & 3071 & 3200 & 3436 & 0.818 & 0.794 & 1.012 & 0.893 & 0.894 & 0.931 & \\
\hline $\mathrm{C} 2-2$ & 2810 & 2727 & 3476 & 3067 & 3071 & 3200 & 3506 & 0.801 & 0.778 & 0.991 & 0.875 & 0.876 & 0.913 & \\
\hline Average & & & & & & & & 0.839 & 0.872 & 1.030 & 0.982 & 0.932 & 0.957 & \\
\hline $\begin{array}{l}\text { Standard } \\
\text { deviation }\end{array}$ & & & & & & & & 0.157 & 0.065 & 0.106 & 0.378 & 0.051 & 0.052 & \\
\hline $\begin{array}{c}\text { Maximum } \\
\text { (Overestimation) }\end{array}$ & & & & & & & & 1.085 & 0.960 & 1.234 & 3.369 & 1.084 & 1.097 & \\
\hline $\begin{array}{c}\text { Minimum } \\
\text { (Underestimation) } \\
\end{array}$ & & & & & & & & 0.337 & 0.686 & 0.880 & 0.781 & 0.816 & 0.850 & \\
\hline
\end{tabular}

** The respective equation is not applicable. 
Table 3. Existing models for unconfined double-skinned CFST columns

\begin{tabular}{|c|c|c|}
\hline Proposer(s) & Formulas & Limitation(s) \\
\hline $\begin{array}{l}\text { Tan and Zhang } \\
\text { (2010) }\end{array}$ & $\begin{array}{l}N=A f_{s s c} \\
f_{s s c}=\left(1.212+a \xi_{\mathrm{ssc}}+b \xi_{s s c}^{2}\right) f_{c k} \\
a=0.1759 f_{s s} / 235+0.974 \\
b=-0.1038 f_{c k} / 20+0.0309 \\
f_{s s}=\frac{A_{s o} f_{s o}+A_{s i} f_{s i}}{A_{s o}+A_{s i}} \quad \xi_{s s c}=\frac{\sum A_{s} f_{s}}{A_{c} f_{c k}}\end{array}$ & \\
\hline $\begin{array}{l}\text { Tao et al. } \\
\text { (2004) }\end{array}$ & $\begin{array}{l}N_{u}=N_{o s c, u}+N_{i, u} \\
N_{o s c, u}=f_{s c y} A_{s c o} \quad A_{s c o}=A_{s o}+A_{c} \\
f_{s c y}=C_{1} \chi^{2} f_{s y o}+C_{2}(1.14+1.02 \xi) f_{c k} \\
C_{1}=\alpha /(1+\alpha) \quad C_{2}=\left(1+\alpha_{n o \min a l}\right) /(1+\alpha) \\
\alpha=A_{s o} / A_{c} \quad \alpha_{n o \min a l}=A_{s o} / A_{c, n o \min a l} \\
\xi=\frac{A_{s o} f_{s y o}}{A_{c, n o \min a l} f_{c k}}\end{array}$ & $\begin{array}{l}\text { Only applicable to } \\
\text { unconfined double-skinned } \\
\text { CFST columns with hollow } \\
\text { section ratio less than } 0.8\end{array}$ \\
\hline $\begin{array}{l}\text { Uenaka et al. } \\
\text { (2010) }\end{array}$ & $N_{u, C F D S T}=\left[2.86-2.59\left(\frac{D_{i}}{D_{o}}\right)\right] A_{s o} f_{s o}+A_{s i} f_{s i}+A_{c} f_{c}^{\prime}$ & $\begin{array}{l}\text { Only applicable to } \\
\text { unconfined double-skinned } \\
\text { CFST columns with } \\
D_{i} / D_{o} \text { ratio between } 0.2 \\
\text { and } 0.7\end{array}$ \\
\hline $\begin{array}{l}\mathrm{Hu} \text { and } \mathrm{Su} \\
\text { (2011) }\end{array}$ & $\begin{array}{ll}P_{n}=P_{o}\left[0.658^{\left(P_{o} / P_{e}\right)}\right] & \text { if } P_{e} \geq 0.44 P_{o} \\
P_{n}=0.877 P_{e} & \text { if } P_{e}<0.44 P_{o}\end{array}$ & \\
\hline
\end{tabular}

analytical model proposed by other researchers (Tao, Han 2006; Tan, Zhang 2010; Uenaka et al. 2010; Hu, Su 2011) and the strength predicted by Eurocode 4 . The comparison is summarised in Table 2(b). The existing models and their respective limitations, if any, are listed in Table 3.

In the table, $N_{p 1}, N_{p 2}, N_{p 3}$ and $N_{p 4}$ represent the predicted load-carrying capacities evaluated by Tan and Zhang (2010), Tao et al. (2004), Uenaka et al. (2010) and $\mathrm{Hu}$ and $\mathrm{Su}$ (2011), respectively. $N_{p}$ is the predicted loadcarrying capacity evaluated by authors' proposed model, $N_{t}$ is the measured load-carrying capacity and $N_{E C}$ is the load-carrying capacity evaluated using Eurocode 4. From the table, it is observed that:

1. The average $N_{p 1} / N_{t}, N_{p 2} / N_{t}, N_{p 3} / N_{t}$ and $N_{p 4} / N_{t}$ ratios for all unconfined double-skinned CFST columns are $0.839,0.872,1.030$ and 0.982 respectively. The maximum differences between the predicted load-carrying capacities by various researchers and the measured values are $23.4 \%$ overestimation (Uenaka et al. 2010) and 66.3\% underestimation (Tan, Zhang 2010).

2. The average $N_{p} / N_{t}$ ratio for all unconfined doubleskinned CFST columns are 0.957 and the standard deviation is 0.052 . The maximum differences between the theoretical and test results are $9.7 \%$ overestimation and $15 \%$ underestimation.

3. Comparing with the average $N_{E C} / N_{t}$ ratio for all unconfined double-skinned CFST columns, which is 0.932 , it is evident that the proposed model can predict more accurately the load-carrying capacity of unconfined double-skinned CFST columns.

From the above, it is seen that the proposed model predicts fairly accurately the uni-axial load-carrying capacity of both ring- and un-confined double-skinned CFST columns. In particular, the proposed model can predict more accurately the axial load-carrying capacity of ring-confined CFST columns than the Eurocode does.

\section{Conclusions}

A new method for providing external confinement to restrict the lateral dilation of double-skinned CFST columns has been proposed and verified previously by uni-axial compression test to have successfully restored the intact interface steel-concrete interface bonding during the elastic stage. Based on the test results, a theoretical model has been built up that takes into account the confining 
effects provided by both steel rings and steel tube for predicting the uni-axial strength of double-skinned CFST columns. The uni-axial load-carrying capacity evaluated by the proposed theoretical model was compared with the experimental results obtained by the authors and other researchers' and it was found that:

1. For ring-confined double-skinned CFST columns with hollow ratio of 0.56 and 0.72 , the theoretical results are in good agreement with the experimental results.

2. For unconfined double-skinned CFST columns with hollow ratios ranging from 0.24 to 0.88 , the theoretical model predicts more accurately the load carrying capacity than Eurocode does.

From the comparison, it is evident that the proposed model can predict the uni-axial load carrying capacity of the unconfined and ring-confined double-skinned CFST columns fairly accurately. The validity of the proposed model needs to be further verified by extensive experimental data of confined double-skinned CFST columns.

\section{Acknowledgements}

The work described in this paper has been substantially supported by a grant from the Research Grants Council of the Hong Kong Special Administrative Region, China (Project No. HKU 712310E). Technical supports for the experimental tests provided by the laboratory staff of the Department of Civil Engineering, The University of Hong Kong, are gratefully acknowledged.

\section{References}

BS EN. 10210-2: 2006. Hot finished structural hollow sections of non-alloy and fine grain steels-Part 2: Tolerances, dimensions and sectional properties. London: British Standards Institute, 2006.

Cai, J.; He, Z. Q. 2006. Axial load behavior of square CFT stub column with binding bars, Journal of Constructional Steel Research 62(5): 472-483. http://dx.doi.org/10.1016/j.jcsr.2005.09.010

Chitawadagi, M. V.; Narasimhan, M. C. 2009. Strength deformation behaviour of circular concrete filled steel tubes subjected to pure bending, Journal of Constructional Steel Research 65(8): 1836-1845.

http://dx.doi.org/10.1016/j.jcsr.2009.04.006

Cusson, D.; Paultre P. 1994. High-strength concrete columns confined by rectangular ties, Journal of Structural Engineering 120(3): 783-804.

http://dx.doi.org/10.1061/(ASCE)0733-9445(1994)120:3(783)

Dabaon, M.; El-Khoriby, S.; El-Boghdadi, M.; Hassanein, M. F. 2009. Confinement effect of stiffened and unstiffened concrete-filled stainless steel tubular stub columns, Journal of Constructional Steel Research 65(8): 1846-1854. http://dx.doi.org/10.1016/j.jcsr.2009.04.012

de Oliveira, W. L. A.; De Nardin, S.; El Debs, A. L. H.; El Debs, M. K. 2010. Evaluation of passive confinement in CFT columns, Journal of Constructional Steel Research 66(4): 487-495 http://dx.doi.org/10.1016/j.jcsr.2009.11.004.

Dong, C. X.; Ho, J. C. M. 2012. Uni-axial behaviour of normalstrength CFDST columns with external steel rings, Steel and Composite Structures 13(6): 587-606. http://dx.doi.org/10.12989/scs.2012.13.6.587

Elchalakani, M.; Zhao, X. L.; Grzebieta, R. 2001. Concretefilled circular steel tubes subjected to pure bending, Jour- nal of Constructional Steel Research 57(11): 1141-1168. http://dx.doi.org/10.1016/S0143-974X(01)00035-9

Elremaily, A.; Azizinamini, A. 2002. Behavior and strength of circular concrete-filled tube columns, Journal of Constructional Steel Research 58(12): 1567-1591.

http://dx.doi.org/10.1016/S0143-974X(02)00005-6

Eurocode 4 (EC4). 2004. Design of composite steel and concrete structures. Part 1.1: General rules and rules for buildings. London: British Standards Institute, 2004.

Ferretti, E. 2004. On poisson's ratio and volumetric strain in concrete, International Journal of Fracture 126(3): 49-55. http://dx.doi.org/10.1023/B:FRAC.0000026587.43467.e6

Gettu, R.; Bazant, Z. P.; Karr, M. E. 1990. Fracture properties and brittleness of high-strength concrete, ACI Materials Journal 87(6): 608-618.

Giakoumelis, G.; Lam, D. 2004. Axial capacity of circular concrete-filled tube columns, Journal of Constructional Steel Research 60(7): 1049-1068.

http://dx.doi.org/10.1016/j.jcsr.2003.10.001

Goldman, A.; Bentur, A. 1993. The influence of microfillers on enhancement of concrete strength, Cement and Concrete Research 23(4): 962-972. http://dx.doi.org/10.1016/0008-8846(93)90050-J

Han, L. H.; Ren, Q. X.; Li W. 2011. Testson stub stailess steelconcrete-carbon steel double-skin tubular (DST) columns, Journal of Constructional Steel Research 67(3): 437-452.

Han, L. H.; Tao, Z.; Huang, H.; Zhao, X. L. 2004. Concretefilled double skin (SHS outer and CHS inner) steel tubular beam-columns, Thin-Walled Structures 42(9): 1329-1355. http://dx.doi.org/10.1016/j.tws.2004.03.017

Haque, M.; Kayali, O. 1998. Properties of high-strength concrete using a fine fly ash, Cement and Concrete Research 28(10): 1445-1452.

http://dx.doi.org/10.1016/S0008-8846(98)00125-2

Hatzigeorgiou, G. D. 2008. Numerical model for the behavior and capacity of circular CFT columns, Part I: theory, Engineering Structures 30(6): 1573-1578. http://dx.doi.org/10.1016/j.engstruct.2007.11.001

Ho, J. C. M.; Luo, L. 2012. Uni-axial behaviour of normalstrength concrete-filled-steel-tube columns with external confinement, Earthquake and Structures 3(6): 889-910. http://dx.doi.org/10.12989/eas.2012.3.6.889

Ho, J. C. M.; Zhou, K. J. H. 2011. Limited deformability design of high-strength concrete beams in low to moderate seismicity regions, Journal of Civil Engineering and Management 17(3): 409-423.

http://dx.doi.org/10.3846/13923730.2011.594219

Hu, H. T.; Su, F. C. 2011. Nonlinear analysis of short concretefilled double skin tube columns subjected to axial compressive forces, Marine Structures 24(4): 319-337. http://dx.doi.org/10.1016/j.marstruc.2011.05.001

Huang, C.; Yeh, Y. K.; Liu, G. Y.; Hu, H. T.; Tsai, K.; Weng, Y. T.; Wang, S. H.; Wu, M. H. 2002. Axial load behavior of stiffened concrete-filled steel columns, Journal of Structural Engineering 128(9): 1222-1230. http://dx.doi.org/10.1016/j.jcsr.2009.09.014

Huang, H.; Han, L. H.; Tao, Z.; Zhao, X. L. 2010. Analytical behaviour of concrete-filled double skin steel tubular (CFDST) stub columns, Journal of Constructional Steel Research 66(4): 542-555.

Huang, Y. H.; Wang, R. H.; Huang, X. F. 2011. Calculation of the interfacial tensile stress of CFST members under axial pressure, Advanced Materials Research 250-253: 1638-1645.

Kitada, T. 1998. Ultimate strength and ductility of state-of-theart concrete-filled steel bridge piers in Japan, Engineering Structures 20(4): 347-354.

http://dx.doi.org/10.1016/S0141-0296(97)00026-6 
Köster, W.; Franz, H. 1961. Poisson's ratio for metals and alloys, Metallurgical Reviews 6(1): 1-56. http://dx.doi.org/10.1179/mtlr.1961.6.1.1

Kuranovas, A.; Goode, D.; Kvedaras, A. K.; Zhong, S. 2009. Load-bearing capacity of concrete-filled steel columns, Journal of Civil Engineering and Management 15(1): 2133. http://dx.doi.org/10.3846/1392-3730.2009.15.21-33

Lai, M. H.; Ho, J. C. M. 2014. Behaviour of uni-axially loaded concrete-filled-steel-tube columns confined by external rings, The Structural Design of Tall and Special Buildings 23(6): 403-426. http://dx.doi.org/10.1002/tal.1046

Lin, M.; Tsai, K. C. 2001. Behavior of double-skinned composite steel tubular columns subjected to combined axial and flexural loads, in Proc. of the First International Conference on Steel and Composite Structures, 14-16 June 2001, Pusan, Korea, 1145-1152.

Lu, H.; Han, L. H.; Zhao, X. L. 2010. Fire performance of selfconsolidating concrete filled double skin steel tubular columns: experiments, Fire Safety Journal 45(2): 106-115. http://dx.doi.org/10.1016/j.firesaf.2009.12.001

Lu, H.; Han, L. H.; Zhao, X. L. 2009. Analytical behavior of circular concrete-filled thin-walled steel tubes subjected to bending, Thin-Walled Structures 47(3): 346-358. http://dx.doi.org/10.1016/j.tws.2008.07.004

Lu, X.; Hsu, C. T. T. 2007. Tangent Poisson's ratio of highstrength concrete in triaxial compression, Magazine of Concrete Research 59(1): 69-77. http://dx.doi.org/10.1680/macr.2007.59.1.69

Mander, J.; Priestley, M. J. N. 1988. Theoretical stress-strain model for confined concrete, Journal of Structural Engineering 114(8): 1804-1825.

http://dx.doi.org/10.1061/(ASCE)0733-9445(1988)114:8(1804)

Marzouk, H.; Chen, Z. 1995. Fracture energy and tension properties of high-strength concrete, Journal of Materials in Civil Engineering 7(2): 108-116.

http://dx.doi.org/10.1061/(ASCE)0899-1561(1995)7:2(108)

Montejo, L. A.; González-Román, L. A.; Kowalsky, M. J. 2012. Seismic performance evaluation of reinforced concretefilled steel tube pile/column bridge bents, Journal of Earthquake Engineering 16(3): 401-424. http://dx.doi.org/10.1080/13632469.2011.614678

O'Shea, M. D.; Bridge, R. Q. 1997. Local buckling of thin-walled circular steel sections with or without internal restraint, Journal of Constructional Steel Research 41(2): 137-157. http://dx.doi.org/10.1016/S0143-974X(97)80891-7

Persson, B. 1999. Poisson's ratio of high-performance concrete, Cement and Concrete Research 29(10): 1647-1653. http://dx.doi.org/10.1016/S0008-8846(99)00159-3

Sakino, K.; Nakahara, H.; Morino, S.; Nishiyama, I. 2004. Behavior of centrally loaded concrete-filled steel-tube short columns, Journal of Structural Engineering 130(2): 180188.

http://dx.doi.org/10.1061/(ASCE)0733-9445(2004)130:2(180)

Schneider, S. P. 1998. Axially loaded concrete-filled steel tubes, Journal of Structural Engineering 124(10): 1125-1138. http://dx.doi.org/10.1061/(ASCE)0733-9445(1998)124: $10(1125)$

Shakir-Khalil, H. 1991. Composite columns of double-skinned shells, Journal of Constructional Steel Research 19(2): 133-152. http://dx.doi.org/10.1016/0143-974X(91)90038-3

Szmigiera, E.; Zoltowski, W.; Siennicki, M. 2010. Research on load capacity of concrete filled columns with battened steel sections, Journal of Civil Engineering and Management 16(3): 313-319. http://dx.doi.org/10.3846/jcem.2010.36

Tan, K. H.; Zhang, Y. F. 2010. Compressive stiffness and strength of concrete filled double skin (CHS inner \& CHS outer) tubes, International Journal of Mechanics and Materials in Design 6(3): 283-291.

http://dx.doi.org/10.1007/s10999-010-9138-y

Tao, Z.; Han, L. H. 2006. Behaviour of concrete-filled double skin rectangular steel tubular beam-columns, Journal of Constructional Steel Research 62(7): 631-646. http://dx.doi.org/10.1016/j.jcsr.2005.11.008

Tao, Z.; Han, L. H.; Wang, D. Y. 2007. Experimental behaviour of concrete-filled stiffened thin-walled steel tubular columns, Thin-Walled Structures 45(5): 517-527. http://dx.doi.org/10.1016/j.tws.2007.04.003

Tao, Z.; Han, L. H.; Wang, Z. B. 2005. Experimental behaviour of stiffened concrete-filled thin-walled hollow steel structural (HSS) stub columns, Journal of Constructional Steel Research 61(7): 962-983. http://dx.doi.org/10.1016/j.jcsr.2004.12.003

Tao, Z.; Han, L. H.; Zhao, X. L. 2004. Behaviour of concretefilled double skin (CHS inner and CHS outer) steel tubular stub columns and beam-columns, Journal of Constructional Steel Research 60(8): 1129-1158.

http://dx.doi.org/10.1016/j.jcsr.2003.11.008

Uenaka, K.; Kitoh, H.; Sonoda, K. 2010. Concrete filled double skin circular stub columns under compression, ThinWalled Structures 48(1): 19-24. http://dx.doi.org/10.1016/j.tws.2009.08.001

Varma, A. H.; Ricles, J. M.; Sause, R.; Lu, L. W. 2002. Seismic behavior and modeling of high-strength composite concrete-filled steel tube (CFT) beam-columns, Journal of Constructional Steel Research 58(5): 725-758. http://dx.doi.org/10.1016/S0143-974X(01)00099-2

Wei, S.; Mau, S. T.; Vipulanandan, C.; Mantrala, S. K. 1995. Performance of new sandwich tube under axial loading: experiment, Journal of Structural Engineering 121(12): 1806-1814. http://dx.doi.org/10.1061/(ASCE)0733-9445 (1995)121:12(1806)

Wright, H.; Oduyemi, T.; Evans, H. 1991. The experimental behaviour of double skin composite elements, Journal of Constructional Steel Research 19(2): 97-110. http://dx.doi.org/10.1016/0143-974X(91)90036-Z

Yang, J.; Xu, H.; Peng, G. 2008. Behavior of concrete-filled double skin steel tubular columns with octagon section under axial compression, Frontiers of Architecture and Civil Engineering in China 2(3): 205-210. http://dx.doi.org/10.1007/s11709-008-0035-5

Yang, Y.; Han, L. H. 2008. Concrete-filled double-skin tubular columns under fire, Magazine of Concrete Research 60(3): 211-222. http://dx.doi.org/10.1680/macr.2007.00074

Young, B.; Ellobody, E. 2006. Experimental investigation of concrete-filled cold-formed high strength stainless steel tube columns, Journal of Constructional Steel Research 62(5): 484-492.

http://dx.doi.org/10.1016/j.jcsr.2005.08.004

Zhao, X. L.; Grzebieta, R. 2002. Strength and ductility of concrete filled double skin (SHS inner and SHS outer) tubes, Thin-Walled Structures 40(2): 199-213. http://dx.doi.org/10.1016/S0263-8231(01)00060-X

Zhao, X. L.; Grzebieta, R.; Elchalakani, M. 2002. Tests of concrete-filled double skin CHS composite stub columns, Steel and Composite Structures 2(2): 129-146. http://dx.doi.org/10.12989/scs.2002.2.2.129

Zhao, X. L.; Tong, L. W.; Wang, X. Y. 2010. CFDST stub columns subjected to large deformation axial loading, Engineering Structures 32(3): 692-703. http://dx.doi.org/10.1016/j.engstruct.2009.11.015

Zhou, F.; Barr, B.; Lydon, F. 1995. Fracture properties of high strength concrete with varying silica fume content and aggregates, Cement and Concrete Research 25(3): 543-552. http://dx.doi.org/10.1016/0008-8846(95)00043-C 


\section{List of Notations}

NSC - Normal-strength concrete;

HSC - High-strength concrete;

RC - Reinforced concrete;

HSCFST - High-strength concrete-filled-steel-tubular;

$D_{i} \quad$ - Outer diameter of inner tube of double-skinned CFST column;

$D_{o} \quad-$ Outer diameter of outer tube of double-skinned CFST column;

$t_{i} \quad-$ Thickness of inner tube of double-skinned CFST column;

$t_{o} \quad-$ Thickness of outer tube of double-skinned CFST column;

$A_{i} \quad$ - Cross-section area of the inner tube;

$A_{o} \quad-$ Cross-section area of the outer tube;

$A_{c c} \quad$ - Cross-section area of the core concrete;

$A_{R} \quad-$ Cross-section area of external steel ring;

c - Hollow section ratio;

$N \quad$ - Load-carrying capacity of a specimen;

$N_{i} \quad$ - Axial load taken by the inner tube;

$N_{o} \quad-$ Axial load taken by the outer tube;

$N_{c c} \quad-$ Axial load taken by the core concrete;

$N_{E C} \quad-$ Axial strength of a specimen evaluated by Eurocode;

$N_{p} \quad$ - Axial strength of a specimen predicted by the proposed model;

$N_{p}{ }^{\prime} \quad$ - Axial strength of a specimen predicted by simplified formula;

$N_{p 1} \quad$ - Axial strength of a specimen predicted by Tan and Zhang (2010);

$N_{p 2} \quad$ - Axial strength of a specimen predicted by Tao et al. (2004);

$N_{p 3} \quad-$ Axial strength of a specimen predicted by Uenaka et al. (2010);

$N_{p 4} \quad$ - Axial strength of a specimen predicted by $\mathrm{Hu}$ and $\mathrm{Su}(2011) ;$

$N_{t} \quad$ - Experimentally measured axial strength of a specimen;

$f_{i} \quad-$ Axial stress of the inner tube;

$f_{o} \quad-$ Axial stress of the outer tube;

$f_{c c} \quad-$ Axial stress of the core concrete;

$f_{c}{ }^{\prime} \quad$ - Uni-axial concrete compressive strength represented by cylinder strength;

$f_{r} \quad$ - Confining pressure;

$\varepsilon_{y} \quad-$ Axial strain at yielding;

$\varepsilon_{l b} \quad-$ Axial strain for local buckling;

$E_{s o} \quad-$ Elastic modulus of outer steel tube;

$\sigma_{\theta, i} \quad$ - Hoop stress in inner tube of double-skinned CFST column;

$\sigma_{\theta, o} \quad$ - Hoop stress in outer tube of double-skinned CFST column;

$\sigma_{R} \quad-$ Tensile stress in external steel ring;

$f_{y, i} \quad$ - Uni-axial yield strength of inner tube of double-skinned CFST column;

$f_{y, o} \quad$ - Uni-axial yield strength of outer tube of double-skinned CFST column;

$f_{y, R} \quad$ - Uni-axial yield strength of external steel ring;

$n$ - Number of external steel bars;

$h \quad-$ Height of the specimen;

$s \quad-$ Spacing of external steel rings;

$\alpha_{\theta} \quad-$ Hoop stress ratio.

Chun Xiao DONG. (MPhil) is a PhD student of the Department of Civil Engineering of The University of Hong Kong. His research deals with the uni-axial behaviour of double-skinned concrete-filled-steel-tubular column with external confinement as well as its respective theoretical model.

Johnny Ching Ming HO. (PhD, MHKIE, MIEAust, CPEng, MIStructE, CEng) is a senior lecturer in the School of Civil Engineering, The University of Queensland. His research interests are on developing scientific mix design for high-performance concrete using multi-sized fillers and its application on concrete-filled-steel-tubular columns. 